\title{
SINERGI POLRI BERSAMA MASYARAKAT DI TANJUNG BALAI KARIMUN DALAM MENCEGAH RADIKALISME DAN PENGAMALAN HADIST INTOLERANSI
}

\author{
Aslati $^{1}$, Silawati $^{2}$, Darmawati ${ }^{3}$, dan M. Fahli Zatrahadi ${ }^{4}$ \\ ${ }^{1}$ Program Studi Pengembangan Masyarakat Islam, Fakultas Dakwah dan Komunikasi, \\ ${ }^{2,4}$ Program Studi Bimbinan Konseling Islam, Fakultas Dakwah dan Komunikasi, \\ ${ }^{3}$ Program Studi Komunikasi, Fakultas Dakwah dan Komunikasi, Universitas Islam Negeri Sultan Syarif Kasim Riau \\ Jl. HR. Soebrantas no. 155 Km. 15 Simpang Baru Panam Pekanbaru 28293 PO. Box. 1004 Telp 0761-56164 \\ E-mail: aslati@uin-suska.ac.id
}

\begin{abstract}
ABSTRAK. Menurut Undang-undang yang berlaku di Indonesia pemerintah bertanggungjawab memberikan rasa aman kepada masyarakat.Oleh sebab itu berbagai upaya yang dilakukan oleh pemerintah untuk menciptakan rasa aman itu diantaranya melakukan upaya pencegahan munculnya kelompok Radikal dan Intoleransi.Yang menjadi Subjek Penelitian adalah Polri melalui fungsi Bhabinkamtibmas serta unsur terkait dan objek penelitian adalah sinergitas Polri bersama masyarakat dalam upaya pencegahan radikalisme dan Intoleransi serta pengamalan hadist. Setelah dilakukan penelusuran data lapangan maka diperoleh kesimpulan bahwa Polres Karimun melalui fungsi Bhabinkamtibmas secara bersinergi dengan seluruh elemen masyarakat berupaya melakukan langkah pencegahan terjadinya tindakan radikalisme dan intoleransi seperti menyambangi warga masyarakat untuk mendengar secara langsung keluhan warga dan berupaya memberi solusi dari permasahan yang terjadi, menciptakan hubungan yang harmonis antara aparat kepolisian dengan masyarakat melalui kegiatan-kegiatan yang bersentuhan langsung dengan warga, memberikan bimbingan atau penyuluhan agama tentang Jihad yang benar menurut Hadits, menyebarluaskan informasi terkait Harkamtibmas, menghidupkan pelaksanaan Siskamling, memberikan pelayanan kepolisian kepada masyarakat, memotivasi kegiatan masyarakat yang bersifat positif, berkoordinasi dengan perangkat desa/kelurahan dan pihak-pihak terkait lainnya serta bertindak sebagai mediator, negosiator dan fasilitator untuk kepentingan warga masyarakat dalam rangka pemecahan masalah kejahatan dan masalah sosial lainnya. Di sisi lain secara berkesinambungan Polres Karimun melaksanan Focus Grup Discussion (FGD) dengan masyarakat dalam hal sosialisasi upaya pencegahan radikalisme dan intoleransi melalui lembagalembaga seperti Kemenag, FKUB, Lembaga pendidikan, Lembaga Agama lembaga Eksekutif, Legislatif dan Yudikatif, Media serta LSM yang ada di Karimun.
\end{abstract}

Kata kunci: Intoleransi; Masyarakat; Polri; Radikal; Sinergi

\section{THE INDONESIAN POLICE AND SOCIETY SYNERGY IN TANJUNG BALAI KARIMUN IN PREVENTING RADICALISM AND INTOLERANT HADITH IMPLEMENTATION}

\begin{abstract}
In the government context, state apparatus have an obligation to provide safety for every citizen. Therefore, the object of this research is the police synergy with society to prevent radicalism and intolerance in the territory of Karimun resort police office of Kepulauan Riau. Research method used is Research and development $(R \& D)$. This research finds that the Karimun resort police office through the function of Bhabinkamtibmas cooperatively with all elements of the society to prevent radicalism and intolerance, namely visiting to social activities to listen the problems of the society about the Kamtibmas (security and order of the society) and providing information and solutions, maintaining or keeping the good relationship, supervising and guiding people in law and security to improve people consciousness based on human rights, provide religious guidance or counseling about true jihad accoding to the hadith, disseminating information about the police policies related to security and social order protection (Harkamtibmas), supporting the implementation of Siskamling (traditional security) to provide safety for people, providing the police service to people needed, actuating the positive society's activities, coordinating the Kamtibmas development with village's apparatus and relevant parties, conducting or providing a consultation, mediation, negotiation, facility, motivation to people in Harkamtibmas and providing solutions for social and criminal problems. Furthermore, the Karimun resort police office continuously conducts Focus Grup Discussion (FGD) with the society to socialize the radicalism and intolerance prevention done through several institutions like Kemenag (Religious Affairs Office), FKUB (Forum for Religious Harmony), Education Institutions, Executive Institutions, Legislative Institutions, Judicative Institutions, Media and NGOs in Karimun.
\end{abstract}

Key words: Intolerance; Indonesian Police; Society; Radicalism; Synergy

\section{PENDAHULUAN}

Dasar dari ketatanegaraan NKRI adalah Pancasila (Pigome, 2011), maka gerakan-gerakan yang bersifat radikalisme di Indonesia akan sangat merugikan ketatanegaraan tersebut. Adanya gerakan radikalismememberikan dampak buruk terhadap sistem negara dimana negara akan dipandang rendah oleh bangsa lain dan yang pasti dampak terhadap masyarakat bahwa masyarakat tidak lagi mendapatkan rasa aman. Hal ini bersesuaian pada pancasila yakni sila yang berkenaan dengan ketuhanan yang Maha Esa dimaksudkan pemahaman dari kalimat ini adalah tidak ada satu agamapun mengajarkan tentang kekerasan apalagi cenderung radikal (Abdillah, 2014). Tindakan intoleransi dan radikalisme berawal dari pemahaman keyakinan tertentu yang paling benar sedangkan kelompok lain yang 
berbeda adalah salah. Sesuatu yang berawal dari intoleransi maka jika dibiarkan akan menjadi radkalisme. Selanjutnya jika bibit radikalisme ini mendapat tempat atau suasana yang kondusif maka akan berkembang menjadi terorisme (Darraz, 2013). Kebanyakan kelompok intoleransi yang berkembang saat ini mengatasnamakan agama tertentu. Dalam perkembangannya mereka menggunakan media teknologi informasi dan media-media sosial lainnya dalam menyebarkan pemahamannya kepada masyarakat dengan memilintir hadits sebagai dasar kebenaran melakukan tindakan radikal (Asrori, 2015). Munculnya konflik sosial ditengah masyarakat membutuhkan cara khsusus untuk pencegahannya, dalam hal ini oleh pemerintah Indonesia melalui aparat terkait yang menangani, salah satunya adalah aparat kepolisian (Prasetyo, 2016).

Keberadaan kelompok radikal dan intoleransi secara umum ditandai dengan oleh gagasan dan pemikiran intoleransi berbentu ujaran kebencian, namun lambat laun hal tersebut berubah menjadi suatu perbuatan dalam bentuk kejahatan kebencian.Kebencian yang ada pada seseorang berawal dari ketidak tenangan jiwa (Hadi, 2015). Adapun yang dimaksud dengan ujaran kebencian adalah perbuatan melalui kata-kata dan tulisan yeng berbentuk hasutan, atau menyulut serta menyebarkan benih kebencian kepada pihak lain dengan cara mempertajam jurang pemisah dan perbedaan, biasanya terkait suku, agama, aliran keagamaan, keyakinan atau kepercayaan, ras, antar golongan, warna kilit serta etnis (Ridho, 2018).

Dalam rangka upaya pencegahan paham radikalisme dan intoleransi yang terjadi di tengah-tengah masyarakat, maka yang bertanggungjawab bukan saja pihak kepolisian namun sangat diperlukan partisipasi seluruh elemen masyarakat. Secara kelembagaan, pencegahan dan penindakan pidana terorisme dilakukan oleh aparat Negara sebagaimana diatur dalam dalam undangundang Nomor 9 tahun 2013 (Republik Indonesia, 2013) tentang pencegahan dan pemberantasan tindak pidana pendanaan terorisme dan Perpres. Nomor 12 tahun 2012 tentang perubahan atas Perpres nomor 46 tahun 2010 tentang Badan Nasional Penanggulangan terorisme. Namun pada aspek lain diperlukan keterlibatan masyarakat secara aktif terhadap pencegahan terorisme dan paham radikal, tingkat penyebaran paham radikal dan intoleransi. Atas semua itu sangat diperlukan antisipasi dari dari seluruh elemen masyarakat dan diharapkan mampu menciptakan keberlangsungan kehidupan sosial bermasyarakat(Terorisme, 2016).

Polri bertugas memberikan pelayanan keamanan dan ketertiban kepada masyarakat maka Polri sudah lama mengindikasikan eksistensi kelompok radikal dan intoleransi di Indonesia.Secara umum langkah-langkah yang dipersiapkan oleh Polri bertujuan untuk pencegahan munculnya kekerasan yang bermuara pada konflik sosial.
Penanganan kelompok radikal dan intoleransi merupakan salah satu program optimalisasi aksi menuju Polri yang semakin professional, modern dan terpercaya (Promoter) melalui fungsi Bintara Pembina Keamanan dan Ketertiban Masyarakat.

Adapun tugas pokok dari Bhabinkamtibmas adalah sebagai garda terdepan (Widjajanto, Perwita, Rezasyah, \& Hersutanto, 2013), atau corong dalam menyampaikan pesan-pesan Polri secara langsung kepada masyarakat dan selanjutnya membangun kesadaran dan partisipasi masyarakat dalam hal keamanan dan ketertiban masyarakat (Kamtibmas).(Surbakti, 1992) Setiap kesatuan Polri di Indonesia mempunyai unit Bhabinkamtibmas, begitu juga dengan Kepolisian Resort Karimun. Menurut informasi awal melalui observasi penelitian bahwa di kabupaten Karimun pernah terdapat aliran Syiah yang mana komunitas masyarakat yang menganut aliran ini sudah berkembang. Hal ini menimbulkan keresahan ditengah masyarakat. Aparat kepolisian bekerjasama dengan aparat pemerintah Kabupaten berupaya mengadakan komunikasi secara intensif serta mengadakan pembinaan dan pendekatan-pendekatan terhadap kelompok tersebut seingga akhirnya saat ini tidak ada lagi kelompok Syiah tersebut.

Kesalahpahaman dalam mengamalkan hadits juga berdampak pada prilaku yang keliru yang bisa jadi dapat membuat orang yang memahami hadits itu berubah menjadi radikal, seperti potongan hadits berikut yang artinya: "Barangsiapa diantara kamu melihat kemungkaran maka cegahlah dengan tangan, kalau ia tidak sanggup (berbuat demikian), maka hendaklah ia mengubah dengan lisannya, dan kalau tidak sanggup (pula), maka hendaklah ia melakukan dengan hatinya (mendo'akan), yang demikian adalah selemah-lemah iman.'(H.R.Ahad, Muslim dan Ashab as-Sunan). Mencegah dengan tangan tersebut bukanlah dimaknai dengan kekerasan, tetapi dengan kekuasaan. Apabila hadis dipahami dengan tekstual saja maka cara penolakan terhadap kemungkaran yang utama dengan cara kekerasan, yang artinya menggunakan tangan. Harusnya masyarakat tahu bahwa tidak semua hadis dapat dipahami secara tekstual. Adakalanya dipahami secara kontekstual (Khamid, 2016).

Pada Maret 2016 terjadi penyerangan terhadap anggota Polsek Balai, setelah dilakukan interogasi diperoleh informasi bahwa pelaku penyerangan mendapatkan paham radikal dari internet. Namun demikian tidak tertutup kemungkinan bahwa kejadian tersebut dapat terulang, hingga perlu diupayakan pencegahan terhadap masuk dan beredarnya paham radikal dan intoleransi terhadap masyarakat di kabupaten Karimun. Dalam rangka penjabaran Program Prioritas Promoter Kepolisian Resort Karimun sangat gencar mengadakan kegiatan-kegiatan yang melibatkan masyarakat dalam Rangka pencegahan 
dan penanganan kelompok radikal pro kekeraan dan intoleransi seperti kegiatan FGD dengan melibatkan MUI, FKUB, Lembaga Pendidikan, Lembaga Eksekutif, Legislatif dan Yudikatif, tokoh masyarakat, tokoh adat.

\section{METODE}

Penelitian ini merupakan jenis penelitian lapangan (Gunawan, 2013) Penelitian lapangan merupakan penelitian kualitatif di mana menggunakan pengamatan dan menjadi partisipan dalam penelitian skala sosial kecil dan mengamati budaya setempat. Roice Singleton (dalam Fatahillah, 2018), penelitian lapangan berasal dari dua tradisi yang terkait yakni antropologi dan sosiologi dimana etnografi merupakan studi antropologi dan etnomethodologi merupakan studi sosiologi.

Pendekatan yang diguankan ialah wawancara mendalam kepada aktor-aktor kunci dan melakukan Focus Group Discussion (FGD) dengan stakeholders kepada anggota komunitas. Secara praktis penelitian dilakukan menggunakan Pendekatan metode Participatory Action Research PAR (Yaumi, 2016). Penelitian ini memperhatikan perubahan sosial, yang melihat proses pemberdayaan dapat mewujudkan tiga tolak ukur, yakni adanya komitmen bersama dengan masyarakat, adanya local leader dalam masyarakat dan adanya institusi baru dalam masyarakat yang dibangun berdasarkan kebutuhan. Informan dalam penelitian ini sebanyak 3 orang dari pihak polres dan 3 dari masyarakat. Analisis data kualitatif menggunakan Teknik Komparatif Konstan dengan menempuh beberapa tahapan analisis yaitu: Pertama, menempatkan data ke dalam kategori-ketegori. Kedua, memperluas kategori tersebut sehingga diperoleh data yang murni dan tidak tumpang tindih satu dengan yang lainnya.Ketiga mencari hubungan antara kategori. Keempat, menyederhanakan dan mengintegrasikan data ke dalam struktur teoritis yang koheren.

\section{HASIL DAN PEMBAHASAN}

Sinergi Polri bersama masyarakat yang dimaksud di sini adalah bagaimana tugas Polri akan lebih bisa terealisasi dan mencapai tujuan dalam pencegahan kelompok radikal pro kekerasan dan intoleransi dilakukan dengan melibatkan masyarakat. Dimulai saat bergulirnya reformasi tahun 1998 banyak perubahan yang terjadi di pemerintahan ditandai dengan bubarnya pemerintahan orde baru dan digantikan dengan pemerintahan reformasi yang dipimpin oleh Presiden BJ. Habibie.

Kapolri dalam meningkatkan integritas dan kedisiplinan anggota yang dibentuk didalam paradigma dan organisasi.Mengingat pada masa Reformasi tidak sedikit dari anggota kapolri tertangkap dan terungkap ke publik sedang melanggar kode etik profersi bahkan juga ada sebagai Polri pada saat itu terjerat hukum seperto, suap, korupsi, rekening gendut, narkoba dan lainnya. Selain kasus hukum diatas, Polri dan TNI juga sering terlibat serang antara anggota yang terjadi dilapangan dan ketegangan antara lembangan penegak hukum masih mewarnai perjalanan reformasi Kepolisian.Adapun tugas pokok dari Kepolisian Negara Republik Indonesia; memberikan perlindungan, pengayoman, dan pelayanan kepada masayarat sehingga merasa memelihara keamanan dan ketertiban masyarakat dalam penegakan Hukum.

Tindakan radikal merupakan perubahan dalam cara berpikir yang dialkukan secara paksaan baik secara politik maupun social (Kamus Besar Bahasa Indonesia). Jika dilaihat dari pandangan keagamaan, radikalisme agama diartikan sebagai pemahaman pada keagamaan yang mengacu kepada pondasi agama yang sangat mendasar dengan fanatisme keagamaan yang sangat tinggi, sehingga dari pemahaman tersebut banyak yang menggunakan kekerasan kepada orang lain yang berbeda paham atau berbeda aliran untuk mengaktualisasikan pemahaman keagamaan yang dianut dan dipercayai untuk dipaksa terima.

Berdasarkan pengertian radikalisme tersebut, maka kesan yang sangat melekat dari gerakan radikalisme itu alah kesan yang negatif, kesan negatif tersebut yaitu adanya tindakan paksaan dan tindakan kekerasandalam upaya mengaktualisasikannya.Adapun dalam konteks ini, semua agama tidak ada yang mengajarkan untuk radikal, sekalipun itu agama Islam yang di identikan selalu melakukan kekerasan. Islam adalah agama yang pengasih dan menebar kebaikan tanpa melakukan kekerasan dan islam merupakan agama yang mengajarkan kasih saying, bersikap lemah lembut, selalu berbuat baik dan adil, serta membangun sikap toleransi. Bahkan didalam Al-Qur'an telah menegaskan bahwa Islam sebagai agama Rahmatan lil 'alamin (pembawa rahmat bagi seluruh alam).Allah SWT berfirman didalam QS. Al-Anbiyah, 107:

"Dan tiadalah Kami utus engkau (ya Muhammad) melainkan sebagai rahmat bagi seluruh alam"

Al-Qur'an diturunkan sebagai pedoman hidup manusia untuk mencapai kebahagian dan kedamaian di dunia dan akhirat.Yang mana kedamaian itu termasuk kedalam kategori kebaikan, oleh karna itu jelas sekali bahwa Al-Qur'an mengajarkan kebaikan dan melarang perbuatan yang tercela (buruk)."Rahmat" berasal dari bahasa Arab yang mempunyai arti kelembutan, pengampunan dan kasih sayang.Agama Islam juga memerintahkan kaum Muslimin untuk menyeru kebaikan dan mencegah kemungkaran. Akan tetapi bila didalam mencegah kemungkaran itu menimbulkan kemungkaran yang lain, maka pencegahan yang seperti ini harus ditinggalkan. Al-Imam Ibnu Qayyim menjelaskan "mencegah kemungkaran itu ada empat tingkatan: 
1. Menyingkirkan kemunkaran dan digantikan dengan lawannya (yaitu kemakrufan);

2. Menyingkirkan kemunkaran dengan menguranginya walau pun tidak menghapuskan secara keseluruhan;

3. Menyingkirkan kemunkaran, tetapi kemudian muncul kemunkaran yang serupa itu;

4. Menyingkirkan kemunkaran tetapi kemudian muncul kemunkaran yang lebih jahat daripadanya.

Dari prinsip-prinsip tersebut dapat dilihat bahwa islam adalah agama yang rahmat bagi kaum mislim dan bagi umat manusia yang lain. Islam merupakan agama yang membenci secara langsung mengenai aksi kezaliman apapun itu bentuknya dan apapun itu alasannya, karan islam agama yang senantiasa mengajarkan dan memerintahkan kepada ummatnya untuk selalu berbuat kedamaian, persahabatan dan harus saling kasih sayang sekalipun dengan agama selain islam. Didalam Al-Qur'an mengatakan bahwa orang yang melakukan aksi kezaliman termasuk orang-orang yang merugi dalam kehidupannya, merugi disini dia tidak akan mendapatkan syurganya Allah. Orang yang melakukan kezaliman dia akan diicap di dunia sebagai pelaku kejahatan dan di akhirat akan dimasukkan di api neraka. Allah SWT, berfirman:

Artinya: Katakanlah, “ apakah akan kami beritahukan kepadamu tentang orang-orang yang paling merugi perbuatannya?" orang yang sedang menyia-nyiakan kehidupannya didunia ini, sedangkan dia merasa perbuatan yang mereka perbuat adalah perbuatan sebaik-baiknya. Orang tersebut adalah orang kafir terhadap ayat-ayat Tuhan mereka dan (Kafir terhadap) perjumpaan dengan Dia. Dan terhapuslaj amalanamalan mereka dan kami tidak menjumpai amalan satu pun dari mereka pada hari kiamat.Demikian balasan mereka itu ialah nerakajahanam, yang disebabkan atas kekafiran mereka dan disebabkan mereka menjadikan ayatOayat-Ku dan rasul-rasul-Ku sebagai bahan olokolok."

Menurut Syariat Islam ada pemahaman yang dikenal dengan Amar Ma'ruf Nahi Mungkar, bahwa amalan ini merupakan amalan yang mengajarkan untuk melihat amal kebaikan dan amal keburukan.Pemahaman ini bisa juga mendatangkan kekeliruan jika dipahami dengan salah dan bisa menimbulkan kekerasan. Rasulullah SAW bersabda mengenai Nahi Munkar:

"Barangsiapa di antara kamu melihat kemungkaran maka ubahlah dengan tangan, kalau tidak sanggup (berbuat demikian), maka hendaklah ia mengubah dengan lisannya, dan kalau tidak sanggup (pula), maka hendaklah ia melakukan dengan hatinya (mendo'akan), yang demikian adalah selemah-lemah iman.'(H.R. Muslim No. 186).
Jika hadis ini dipahami secara tekstual, maka nahi mungkar akan dipahami dengan cara kekerasan, yaitu dengan tangan. Tidak semua hadis dan ayat Al-Qur'an dapat di pahami dengan cara tekstual, melainkan dengan cara penafsiran yang dilakukan oleh para ulama-ulama. Adapun penafsiran secara kontekstual arti dari mencegah dengan tangan itu bukan termasuk dengan kekerasan, akan tetapi dengan kekuasaan. Artinya mencegah kemungkaran dengan kekuasan yang dimiliki, seperti pemimpi harus mencegah kemungkaran yang dilakukan oleh bawahannya dari perilaku kemungkaran yang dimana perilaku tersebut dapat mencelakakan diri sendiri. Contoh yang lain seperti orang tua yang melarang anaknya untuk melakukan kemungkaran karna orang tua mempunyai kekuasan atas anaknya, begitu seterusnya.

Rasulullah bersabda dan mengeluarkan pesan kepada sahabatnya ketika dalam penyebaran agama Islam (HR. Muslim no. 4622):

"Gembirakanlah, jangan kamu buat mereka lari (karena ketakutan), dan mudahkanlah, jangan kamu persulit”.

Dalam sudut pandang Islam salah satu yang menyebabkan munculnya paham radikalisme adalah disebabkan oleh kedangkalan ilmu dalam memahami agama. Hal ini telah membawa persoalan yang cukup serius dalam mempertajam perpecahan dan tindakan inoleran diantara umat Islam, yaitu di mulai dari munculnya Khawarij yang memberontak dan keluar dari barisan Ali bin Abi Thalib, setelah terjadi perang Shiffin antara pasukan Ali melawan Mu'awiyah bin Abi Sufyan yang kemudian berakhir dengan proses tahkim (perundingan) atau arbitrase yang pada akhirnya memutuskan penurunan Ali bin Abi Thalib dari kursi Kekhalifahan. Gerakan kaum Khawarij itu merupakan paham ekstrem dan radikal pertama yang mewarnai sejarah umat Islam yang kemudian berpengaruh terhadap paham-paham keagamaan yang muncul belakangan di dalam Islam.

Intoleransi merupakan kebalikan dari kata toleransi. Yang memiliki arti ialah sikap yang mencerminkan adanya kebencian, iri hati, saling tidak memahami, tidak mau mengalah, dan lebih mementingkan diri sendiri atau kepentingan golongan sendiri.Mereka tidak menghargai atas hak yang telah dititipkan Tuhan kepada mereka. Mereka akan selalu mengatakan bahwa mereka adalah benar, ikuti atau tertindas, ikuti atau pergi. Sajarawan Inggris pada abad ke-19 bernama Arnold Toynbee, pembentukan agama yang menganiaya agama lain karna "dianggap salah", ironisnya membuat agama yang menganiaya agama lain itu menjadi salah dan merusak legitimasinya sendiri. Konsep modern yang mengenai intoleransi berkembang dari kontroversi religious antara Agama Kristen dan Agam Katolik pada abad ke-17 dan 
abad ke-18 di Inggris. Doktrin yang mengenai "Toleransi beragama" pada saat itu bertujuan untuk menghapuskan sentiment-sentimen dan dogma-dogma beragama dari kekuasaan politik.

Intoleransi tidak cukup hanya dimaknai dengan kekerasan perbedaan agama. Intoleransi seharusnya dilihat dari rangkaian atau proses yang membantu dalam memahami bagaimana cara-cara penyebaran kata-kata, ide dan aksiaksi yang bernuansa kebencian yang terkait dengan praktik kekerasan. Beberapa ahli memposisikan intoleransi dan kekerasan terhadap agama itu adalah suatu dua hal yang berbeda. Jika intoleransi itu dilihat dari simbolis, imajinasi, fantasi dan retoris, maka berbeda dengan kekerasan agama yang dilihat secara nyata dan actual.

Polri sebagai Katalisator yang bertugas sebagai pendorong terwujudnya toleransi dan sebagai penetralisir terhadap perbedaan pendapat yang dimana perbedaan tersebut bisa menimbulkan konflik serta mempercepat proses kerukunan dan toleransi. Polri sebagai Negosiator yaitu nego yang berarti perundingan, maka disini sebagai seorangjuru perunding atau penengah dalammengatasi dan menyelesaikan permasalahan yang ada dan mewujudkan persatuan dan kesatuan bangsa. Polri memiliki kebijakan; pertama, Proactive Policing Strategy yaitu deteksi dini, primitive, preventive sebagai langkah awal dalam mengatasi konflik agar tidak terjadi konflik yang terbuka. Kedua, koodinatif dan sinergitas yaitu penyelesaian yang dilakukan harus komprehensif, dalam artian harus mampu melibatkan semua orang didalam menyelsaikan konflik tersebut, termasuk elemen masyarakat dan pemerintah secara sinergis. Ketiga, cegah intoleransi yaitu melakukan pencegahan sedari dini mungkin supaya intoleransi itu tidak meluas dan menghacurkan persatuan dan kesatuan bangsa. Keempat, penindakan tegas terhadap tindakan intoleransi yaitu memberikan tindakan hukum secara tegas bagi yang melakukan tindakan intoleransi tersebut.

Adapun cara-cara polisi dalam upaya pencegahan proses radikalisme dengan cara menetralisi orang-orang yang berpotensi menjadi orang yang melakukan perekrutan dengan mengenali kelompok inti, pendukung dan simpatisan dengan melenahkan ideology radikal yang mereka coba sebarkan dengan membuat ideology yang baru yang bersifat moderat dengan cara memblokir media social dan melakukan penyebaran ideology tandingan tersebut kepada kelompok masyarakat yang rentan terkena radikalisme melalui media social dan melakukan bimbingan dan penyuluhan, dengan memahami konteks social dan budaya yanag ada akan lenih mudah untuk melakukan bimbingan dan penyulihan disetiap lapisan masyarakat dengan memanfaatkan kearifan local secara mengawai media yang menjadi sarana penyebaran paham radikalisme yakni media social, media elektronik dan media cetak.
Secara umum kepolisian melakukan strategi pendekatan lintas sektoral dalam rangka upaya pencegahan radikalisme dan intoleransi yaitu:

1. Galang dan deradikalisasi yang dilakukan terhadap jaringan radikal apabila telah ada dan tumbuh di wilayah baik kelompok atau perorangan dengan memberdayakan ormas atau agama.

2. Koodinasi terpadu antara Polri, TNI, Pemda untuk pendekatan deteksi dini dan dengan melakukan uoaya pro aktif untuk mencegah radikalisasi serta penindakan yuridis terhadap bibit-bibit tindakan radikal.

3. Monitoring Lapas. Back up monitoring apabila wilayah masing-masing terdapat Lapas yang didalamnya terdapat Napi teroris tentang kegiatan dan tingkah lakuk mereka.

4. Monitoring eks Napi yakni back up monitoring diwilayah masing-masing apabila terdapat warga eks napi terror yang telah bebas dan kembali ke lingkungannya.

5. Berdayakan Polmas yakni penguatan system Swakarsa serta memberdayakan tiga pilar Polmas untuk pencegahan

Sebagaimana dijelaskan pada bab pendahuluan bahwa yang dimaksud sinergitas Polri bersama masyarakat dalam upaya pencegahan radikalisme pro kekerasan dan intoleransi yang dilakukan oleh Polres Karimun penulis fokuskan pada fungsi Bhabinkamtibmas sebagai pelaksanan tugas tersebut. Maka uraian berikut adalah melihat lebih dekat tentang keberadaan Satuan Bhabinkamtibmas di tubuh Pori. Berdasarkan Keputusan Kepala Kepolisan Negara RI No.Pol Kep./8/II/2009 tentang perubahan buku petunjuk lapangan Kapolri No. Pol:BUJUKLAP/17/ VII/1997 tentang sebutan Bintara Pembina Keamanan dan Ketertiban Masayarakat (Babin kambitmas) menjadi Bhayangkara Pembinaan Kamtibmas (Bhabinkamtibmas) dari ting-katan kepangkatan Brigadir sampai dengan Inspektur. Sedangkan menurut pasal 1 ayat 4 peraturan kapolri nomor3 tahun 2015 tentang masyarakan dikenakan sangsi pemolisian dengan Bhabinkamtibmas yang dimasud adalah pengemban Polmas di desa/kelurahan.

Melaksanakan kunjungan kepada masyarakat dengan bertujuan utnuk medengarkan keluhan warga masyarakat mengenai permasalahan yang dihadapi tentang Kamtibmas dan memberikan bimbingan penjelasan serta cara penyelesaiannya dan memelihara hubungan silaturahmi yang baik. Membimbingan dan melakukan penyuluhan di bidang hukum dan Kamtibmas dengan tujuan untuk meningkatkan kesadaran akan hukum dan Kamtibmas dengan menjujung tinggi HAM. Dan melakukan penyebarluasan informasi tentang kebijakan pimpinan Polri yang bertkaitan dengan pemeliharaan keamanan dan ketertiban masyarakat (Harkamtibmas). Mendorong pelaksanaan siskamling dalam 
pengamanan lingkungan dan kegiatan masyarakat dengan mengkoordinasikan upaya pembinaan Kamtibmas dengan perangkat deasa dan pihak-pihak disekitar termasuk didalamnya masayrakat sekitar, menggerakkan kegiatan masyarakat yang bersifat positif dengan memberikan pelayanan kepolisian kepada masayrakat yang memerlukan dalam melaksanakan konsltasi, mediasi, negosiasi, fasilitasi, motivasi kepada masyarakat dalam Harkamtibmas dan pemecahan masalah yang terjadi dan kejahatan yang terjadi dilingkungan masyarakat.

Adapun tugas pokoknya adalah memberikan pembinaan kepada masyarakat, medeteksi dan melakukan mediasi/ negosisasi supaya terciptanya kondisi yang kondusif di desa atau kelurahan setempat. Dalam melaksanakan tugasnya, Bhabinkamtibmas melakukan beberapa kegiatan kunjungan darirumah ke rumah di seluruh wilayah sekitar dengan memberikan perlindungan sementara kepada masyarakat, orang yang tersesat dan orang yang mengalami kejahatan supaya masyarakat sekitar dapat meberikan informasi tentang terjadinya tindak pidana agar dapat di tindak secara lanjut, dan melakukan pembantuan untuk memecahkan masalah yang terjadi dan melakukan pengaturan dan pengamanan kegiatan masyarakat dengan mengikut sertakan dalam memberikan bantuan kepada masyarakat terutama kepada korban bencana alam dan wabah penyakit dan memberikan bimbingan kepada masyarakat atau komunitas yang ada terkait dengan Kamtibmas dan Pelayanan Polri.

Adapun wewenang yang dimiliki Bhabinkamtibmas untuk menyelesaikan perselisihan yang terjadi di kalangan masyarakat atau komunitas dengan mengambil langkahlangkah yang diperlukan sebagai tindak lanjut kesepakatan FKPM dalam memlihara keamanan lingkungan masyarakat, dengan menumbuhkan dan mengawasi aliran yang di percayai oleh masyarakat yang dimana kepercayaan itu dapat juga menimbulkan perpecahan dan mengancam persatuan dan kesatuan bangsa dengan mendatangi tempat kejadian perkara (TKP) dan melakukan tindakan awal ditempat tersebut.

Dalam rangka pencegahan radikalisme dan intoleransi maka seluruh elemen masyarakat harus berperan aktif yakni terus menjaga kebhinekaan dan sosialisasi 4 pilar sebagai berikut, pertama: Lembaga Pendidikan, dalam hal ini menanamkan pemahaman sejak dini bahwa perbedaan bukanlah sesuatu yang harus dipertentangkan, namun harus menjadi kekuatan yang saling melengkapi, kedua: Tokoh Masyarakat, Tokoh Agama dan Tokoh Daerah berperan membangun kesadaran dan memberikan arahan contoh serta tauladan dalam kehidupan yang penuh dengan keharmonissan dan toleransi, ketiga: Eksekutif, Legislatif dan Yudikatif berperan menjamin kehidupan yang penuh dengan toleransi dan harmonisasi melalui: a) penguatan regulasi dan penerapannya, b) mengalokasikan dukungan aanggaran agar badan, struktur dan system dapat bekerja dalam kehidupan masyarakat sehingga tercipta nilai-nilai kebhinnekaan, c) mencegah dan mengatasi ancaman terhadap kebhinekaan

Upaya pencegahan Radikalisme pro kekerasan dan intoleransi tak dapat mengabaikan peran masyarakat luas dan lingkungan sosial. Kontribusi masyarakat sangatlah besar, baik dalam konteks memutus ideologisasi, mendeteksi keberadaan kelompok teroris, maupun dalam mengontrol tindak-tanduk jaringan kekerasan ini.Bahkan, peran masyarakat dan lingkungan juga sangat signifikan dalam mengungkap jaringan terorisme.Masyarakat berhak mendapatkan apresiasi setinggi-tingginya atas peran yang dilakukannya. Masyarakat dan lingkungan sosial juga bisa berperan dalam upaya pencegahan dan pendeteksian dini terhadap potensi radikalisme dan intoleransi.Bahkan, perannya dapat dioptimalkan sebagai sarana melakukan upaya preventif dalam memutus rantai terorisme sampai ke akarnya.

Untuk kepentingan sajian data temuan penelitian maka dilakukan wawancara secara intensif terhadap informan penelitian yang sudah ditetapkan pada bab metodologi sekaligus data-data dokumentasi yang diperoleh dari data-data di Polres Karimun melalui Kasium. Wawancara dilakukan terhadap Kasat Bimas, Kanit Bimas, Personil Bhabinkamtibmas. Selanjutnya data lapangan diperoleh melalui wawancara dengan informan pendukung dari unsur masyarakat yakni Ketua FKUB, Ketua Dai, Kepala Kantor Kemenag, Tokoh Pendidikan Kabupaten Karimun.

Dalam rangka pencegahan kasus-kasus radikalisme dan intoleransi maka Polres Karimun berupaya secara intensif melakukan sosialisasi melalui berbagai kegiatan dengan melibatkan stakeholder atau pemangku kepentingan dan masyarakat secara langsung yang secara umum pelaksana kegiatan ini adalah dari unit Bhabinkamtibmas. Hal ini diungkapkan oleh Kapolres Karimun melalui Kasat Bimas. Pada kesempatan lain juga diungkapkan oleh bapak Iptu N, Bripka U dan Bripka A sebagai berikut.

1. Sambang warga

Dalam kegiatan sambang warga yang dilakukan oleh personil Bhabinkamtibmas yaitu dengan cara door to door ke rumah-rumah warga secara kontinyu, gunauntuk mendengarkan keluhan warga masyarakat tentang permasalahan Kamtibmas dan memberikan penjelasan serta penyelesaiannya, memelihara hubungan silaturahmi/ persaudaraan. Dalam melakukan sambang warga yang dilakukan oleh Bhabinkamtibmas juga dikenal dengan istilah 4 D 1C yakni dating, duduk, dengar, dialog dan catat. Kegiatan ini dapat dilakukan dimana saja, seperti dirumah-rumah warga, warung, toko dan tempat-tempat yang ada komunitas atau kumpulan-kumpulan warga. 
2. Pembimbingan dan penyuluhan

Bimbingan dan penyuluhan ini bertujuan untuk meningkatkan rasa nasionalisme dan kepatuhan terhadap Negara Kesatuan Republik Indonesia (NKRI). Bimbingan dan penyuluhan ini juga untuk mencegah masuknya paham radikal dan Intoleransi masuk ke wilayah hukum Polres Karimun.Kegiatan ini bertujuan untuk mencegah paham radikal (deradikalisme) seperti ISIS yang sangat anti dengan Pancasila.

Bhabinkamtibmas menyambangi warga dengan cara Door To Door System (DDS) di seluruh desa yang ada di yang ada di wilayah hukum Polres Karimun. Kegiatan diisi dengan memberikan sosialisasi tentang paham radikal yang anti Pancasila. Dalam kegiatan ini, Bhabinkamtibmas mendatangi para tokoh agama, tokoh adat dan tokoh masyarakat. Bhabinkamtibmas juga mendatangi setiap ada perkumpulan warga seperti warung kopi, tempat ibadah, bengkel, kantor desa, petani, mahasiswa yang sedang melaksanakan KKN dan tempat-tempat keramaian lainnya. Selain memberikan pesa-pesan Kamtibmas para Bhabinkamtibmas juga mengingatkan kepada masyarakat bila ada pendatang yang mengunjungi desanya bila mencurigakan agar segera melaporkan kepada tiga pilar desa, Bhabinkamtibmas, Babinsa dan Kepala Desa.

3. Penyebarluasan informasi

Setiap wilayah kelurahan atau desa peran Bhabinkamtibmas adalah sebagai garda terdepan untuk menangani permasalahan hukum yang terjadi di masyarakat.berbagai upaya penyebaran informasi terkait bahaya radikalisme dan intoleransi dilakukan oleh Bhabinkamtibmas diantaranya memasang stiker tempat-tempat keramaian warga, yang berisi himbauan tentang paham Radikalisme dan dan intoleransi. Penyebaran Informasi juga dilakukan melalui mediamedia social.

Selain itu penyebaran informasi dilakukan sebagaimana arahan Kapolri yakni dengan memperkenalkan ilmu pengetahuan, memberikan pemahaman keilmuan yang benar, memberikan pemahaman yang benar tentang nilai-nilai Pancasila, meminimalisir kesenjangan sosial, menjaga persatuan dan kesatuan, mendukung aksi perdamaian dan berperan aktif mencegah masuknya paham radikalisme dan terorisme.

4. Siskamling

Salah satu upaya yang dilakukan institusi Polri dalam menciptakan keamanan dan ketertiban danmenciptakan rasa aman dan nyaman adalah pembentukan dan pembinaan sistim keamanan lingkungan yang kita kenal dengan sebutan Siskamling. Dalam menjalankan tugas Siskamling Bhabinkamtibmas bekersama dengan aparat kelurahan atau desa, pemuda dan warga masyarakat. Tugas tersebut mencakup melakukan pendataan warga secara berkala, mengecek rumah-rumah kos/sewa serta mewaspadai pendatang yang tidak mempunyai kartu identitas.

Saat ini kegiatan Siskamling sudah dipengaruhi oleh perkembangan media teknologi. Disamping kegiatan Siskamling yang dilakukan secara konvensional juga sudah dilakukan Siskamling di media sosial (Medsos). Caranya dengan membentuk grup-grup messenger di setiap RT dan RW. Selanjutnya dari informasi di Medsos tersebut diharapkan terdeteksi hal-hal yang terjadi di lingkungan masyarakat terutama masalahmasalah sosial yang mengarah kepada tindakan radikalisme dan intoleransi.

5. Pelayanan.

Dalam membangun kerjasama yang bersinergi dengan masyarakat mencegah tindakan radikalisme dan intoleransi dalam hal ini Bhabinkamtibmas selalu memberikan pelayanan prima kepada masyarakat dengan berpartisipasi aktif dalam kegiatan masyarakat seperti menghadiri setiap undangan warga, pengajian yang diadakan warga, memberi solusi kepada masyarakat yang melaporkan setiap gangguan keamanan, menghadiri gotong royong warga

6. Menggerakkan kegiatan masyarakat yang bersifat positif.

Dalam rangka pencegahan radikalisme dan intoleransi di wilayah hukum Polres Karimun melalui fungsi Bhainkamtibmas melakukan upaya mengajak masyarakat melakukan kegiatan-kegiatan positif seperti Siskamling, olahraga bersama, gotong royong dan kegiatan-kegiatan social yang mempersempit gerakan radikalisme dan intoleransi.

7. Koordinasi.

Bhabinkamtibmas bertugas sebagai penyapai pesanpesan dari Kamtibmas secara umum serta melakukan koordinasi ke aparat desa atau kelurahan dalam situasi Kamtibmas di wilayah polres Karimun. Perlunya koordinasi ini dikarenakan Bhabinkamtibmas tidak dapat selalu hadir di di Desa atau di Kelurahan binaan. Oleh karena itulah, diperlukan kerjasama dan saling mengkoorsinasikan secara baik antara Bhabinkamtibmas dengan Kepala Desa, Kepala Suku, Lurah, Camat, RT, dan RW serta Tokoh masyarakat yang ada di sekitar, tujuannya lain tidak bukan hanyalah untuk selalu terjalin komunikasi dalam menyelsaikan permasalahan. Adapun tindakan yang dilakukan oleh Bhabinkamtibmas ini merupakan suatu wujud layanan masyarakat yang di lakukan oelh Bhabinkamtibmas supaya terjaga kamtibmas diwilayah tersebut. Tujuan yang lain ialah untuk mendakatkan diri dengan masyarakat, sehingga masyarakat merasa aman, tentram, dan tidak merasa kegelisahan lagi yang di karenakan keamanan tidak ada. 
8. Konsultasi, mediasi, negosiasi, fasilitasi dan motivasi Upaya pencegahanyang dilakukan oleh Polres Karimun melalui fungsi Bhabinkamtibmas selanjutnya adalah melakukan konsultasi dengan pihak internal Polri itu sendiri yakni kepada atasan dan atasan akan memberikan arahan-arahan terkait tugas Kamtibmas yang akan dilaksanakan oleh anggota Bhabinkamtibmas. Adapun konsultasi dengan pihak eksternal Polri adalah dengan tokoh masyarakat serta aparat terkait.Pada tugas mediasi, Bhabinkamtibmas melakukan langkah-langkah mediasi untuk mencari solusi jika timbul permasalahan ditengah masyarakat terkait usaha-usaha radikalisme dan kasuskasus intoleransi.

Dalam hal negosiasi yang dilakukan oleh Bhabinkamtibmas jika muncul permasalahan kamtibmas maka anggota Bhabinkamtibmas bertindak sebagai negosiator untuk mencari solusi pemecahan masalah tersebut. Selanjutnya sebagai fasilitator Bhabinkamtibmas dituntut untuk bisa memfasilitasi masyarakat dan beruapaya menyelesaikan masalah tersebut melalui forum-forum yang lebih tepat seperti FKPM ataupun bermitra dengan instansi pemerintah di tingkat desa, kelurahan dan stakeholder yang ada ditengah masyarakat.Tugas terakhir dalam rangka upaya pencegahan radikalisme dan intoleransi yang dilakukan oleh Polres Karimun melalui fungsi Bhabinkamtibmas adalah memberikan motivasi kepada masyarakat terkait peran serta dalam pencegahan terjadinya tindakan radikalisme dan intoleransi.

Kasus-kasus radikalisme dan intoleransi dapat diminimalisir apabila terjadi sinergi aparat kepolisian dengan masyarakat, dalam hal ini segala unsur masyarakat dapat melakukannya melalui berbagai sosialisasi yang dilakukan diantaranya melalui :

1) Lembaga Pendidikan

Sosalisasi pencegahan radikalisme dan intoleransi kepada siswa dilakukan oleh pihak sekolah yaitu menanamkan pemahaman sejak dini bahwa perbedaan bukanlah sesuatu yang harus dipertentangkan, namun harus menjadi kekuatan yang saling melengkapi. Dalam hal ini juga pihak kepolisian mengadakan penyuluhanpenyuluhan ke sekolah-sekolah dalam berbagai jenjang pendidikan.

2) Tokoh masyarakat, Tokoh Adat, Tokoh Pemuda Membangun kesadaran \& memberikan arahan, contoh serta tauladan dalam kehidupan yangg penuh dengan keharmonisan \& toleransi

3) Lembaga Eksekutif, Legislatif dan Yudikatif Menjamin kehidupan yang penuh dengan toleransi \& harmonisasi melalui:

a. Penguatan regulasi \& penerapannya

b. Mengalokasikan dukungan anggaran agar badan, struktur \& sistem dapat bekerja dalam kehidupan masyarakat sehingga tercipta nilai-nilai kebhinnekaan

c. Mencegah \& mengatasi ancaman terhadap kebhinnekaan

Selanjutnya dalam pencegahan radikalisme dan intoleransi oleh Polri bersinergi dengan masyarakat pada umunya menggunakan pendekatan kultural dalam mencegah penyebaran pahan radikal dan intoleran hal ini didasarkan fakta bahwa tidak ada satupun kultur masyarakat terutama di Kabupaten Karimun yang memberi celah pada prilaku anarkis, sekalipun hal itu dilakukan atas nama agama karena radikalisme dan intoleransi menjadi paham yang inculture atau bertentangan dengan nilai-nilai budaya luhur masyarakat. Pendekatan kultural diyakini mampu menjadi alternatif dalam mencegah dan membendung paham radikalisme dan intoleransi karena mampu menyentuh langsung ke akar masalahnya yakni terkait dengan masalah lokal seperti kebijakan, keterasingan dan kemiskinan.

\section{SIMPULAN}

Untuk menciptakan Karimun terbebas dari cengkraman radikalisme, ektrimisme dan terorisme semua pihak (eksekutif, legislatif, yudikatif, media, masyarakat) bersinergi yang kuat, membuat program/terobosan yang menyentuh sendi-sendi kehidupan serta implementasi program yang terus menerus/berkesinambungan, dengan sasaran untuk penghapusan atau mematikan radikalisme (individu, kelompok, narasi, infrastruktur dan tindakan atau perbuatannya). Hal ini sudah diupayakan oleh Polres Karimun melalui fungsi Bhabinkamtibmas dengan cara bersinergi dengan seluruh unsur masyarakat dalam rangka mendukung visi misi Polri untuk menciptakan suasana kondusif di tengah dalam kehidupan beragama dan bernegara.

\section{DAFTAR PUSTAKA}

Abdillah, J. (2014). Radikalisme Agama: Dekonstruksi Tafsir Ayat-Ayat "Kekerasan" Dalam Al-Qur'an. KALAM, 8, (2), 281-300.

Asrori, A. (2015). Radikalisme Di Indonesia: Antara Historisitas dan Antropisitas. Kalam, 9, (2), 253268.

Darraz, M.A. (2013). Radikalisme dan Lemahnya Peran Pendidikan Kewargaan. Dalam Menghalau Radikalisasi Kaum Muda: Gagasan Dan Aksi. Jakarta: Jurnal Institut Maarif, 8, 154-173.

Fatahillah, N.C. (2018). Penerapan kisah Rasulullah dalam menjaga kehormatan keluarga di Bulak Banteng Kenjeran Surabaya. Surabaya: UIN Sunan Ampel. 
Gunawan, I. (2013). Metode penelitian kualitatif. Jakarta: Bumi Aksara.

Hadi, M.F.Z. (2015). Tasawuf untuk Kesehatan Mental. An-Nida, 40, (1), 31-41.

Khamid, N. (2016). Bahaya radikalisme terhadap NKRI. Millati: Journal of Islamic Studies and Humanities, 1, (1), 123-152.

Pigome, M. (2011). Implementasi Prinsip Demokrasi dan Nomokrasi dalam Struktur Ketatanegaraan RI Pasca Amandemen UUD 1945. Jurnal Dinamika Hukum, 11, (2), 335-348.

Prasetyo, D. (2016). Sinergi TNI-Polri dalam Deradikalisasi Terorisme di Indonesia. Jurnal Keamanan Nasional, 2, (1), 35-58.

Republik Indonesia. (2013). Undang-Undang Nomor 9 Tahun2013tentangPencegahandanPemberantasan Tindak Pidana Pendanaan Terorisme. Retrieved from Menteri Hukum dan HAM website: https:// www.ojk.go.id/apu-ppt/id/peraturan/uu/Pages/ Undang-Undang-Nomor-9-Tahun-2013-tentangPencegahan-dan-Pemberantasan-Tindak-PidanaPendanaan-Terorisme.aspx

Ridho, M. (2018). Ujaran Kebencian dalam Dakwah: Analisis tentang Pengejawantahan Ide Amar Ma'ruf Nahi Mungkar di Kalangan Para Da'i di Kalimantan Timur. LENTERA, 2, (1), 27-48.

Surbakti, R. (1992). Memahami ilmu politik. Jakarta: Grasindo.

Terorisme, B.N.P. (2016). Strategi Menghadapi Paham Radikalisme Terorisme-ISIS. Jakarta: Belmawa.

Widjajanto, A., Perwita, A.A.B., Rezasyah, T., \& Hersutanto, B. (2013). Penataan Kebijakan Keamanan Nasional. Jakarta: Dian Cipta.

Yaumi, M. (2016). Action Research: Teori, model dan aplikasinya. Jakarta: Prenada Media. 